\title{
RIPARIAN VEGETATION AFFECTED BY BANK EROSION IN THE LOWER SÃO FRANCISCO RIVER, NORTHEASTERN BRAZIL ${ }^{1}$
}

Francisco Sandro Rodrigues Holanda ${ }^{2}$, Laura Galvão da Cunha Santos ${ }^{3}$, Cícero Marques dos Santos ${ }^{3}$, Ana Patrícia Barreto Casado ${ }^{3}$, Alceu Pedrotti² and Genésio Tâmara Ribeiro²

\begin{abstract}
Changes in the hydrological regime of the Lower São Francisco River, located in Northeastern Brazil have brought negative environmental impacts, jeopardizing the flora and fauna of a global biodiversity hotspot, due to implementation of hydroelectric power dams and surface water withdrawal for irrigation in public and private perimeters. Remnants of the riparian stratum associated to the riverbank destabilization in six fragments were studied by surveying trees, shrubs, herbs, and aquatic species. The calculation of the Factor of Safety (FS) was performed in order to understand the riverbank's stability related to soil texture and vegetation cover. An overall number of 51 botanic families distributed in 71 genera and 79 species were recorded, predominantly from the families Mimosaceae, Myrtaceae, and Fabaceae. The fragmented riparian vegetation is mostly covered by secondary species under a strong anthropogenic impact such as deforestation, mining and irrigation, with an advanced erosion process in the river margins. Strong species that withstand the waves present in the river flow are needed to reduce the constant landslides that are mainly responsible for the river sedimentation and loss of productive lands. A lack of preservation attitude among the local landholders was identified, and constitutes a continuing threat to the riparian ecosystem biodiversity.
\end{abstract}

Key words: Floristic survey, riparian vegetation, riverbank destabilization and São Francisco River.

\section{VEGETAÇÃO CILIAR AFETADA PELA EROSÃO NA MARGEM DO BAIXO SÃO FRANCISCO, NORDESTE DO BRASIL}

\begin{abstract}
RESUMO - Mudanças no regime hidrológico no baixo curso do rio São Francisco, localizado na Região Nordeste do Brasil, trouxeram impactos negativos, como a ameaça à fauna e à flora em um dos 25 "hotspots" do mundo para a conservação da biodiversidade, em razão da construção de usinas hidroelétricas e retiradas de água para irrigação em perímetros de irrigação públicos e privados. Foram estudados remanescentes da vegetação ciliar associados com a desestabilização dos barrancos do rio, em seis fragmentos de mata, por meio de levantamento florístico e histórico de degradação dos ecossistemas. Foi também realizado o cálculo do Fator de Segurança (FS), objetivando compreender a estabilidade dos taludes, relacionando com textura do solo e cobertura vegetal. Foi identificado um número total de 51 famílias botânicas, distribuídas em 71 gêneros e 79 espécies, predominantemente das famílias Mimosaceae, Myrtaceae e Fabaceae. A fragmentada vegetação ciliar, predominantemente dominada por espécies secundárias, sofreu forte pressão antropogênica pelos desmatamentos, mineração e irrigação, sob um avançado processo erosivo nas suas margens. Se faz. necessária a revegetação com espécies que suportam a ação das ondas contra os barrancos, visando reduzir
\end{abstract}

\footnotetext{
${ }^{1}$ Recebido em 13.02.2004 e aceito para publicação em 25.11.2004.

${ }^{2}$ Universidade Federal de Sergipe, Cidade Universitária Prof. José Aloisio de Campos, Av. Mal. Rondon, s/n, Jardim Rosa Elze, São Cristovão-SE, 49.100-000, Brazil, E-mail: <fholanda@infonet.com.br>.

${ }^{3}$ Universidade Federal de Sergipe - Master Course in Environment and Development.
} 
os constantes desmoronamentos de grandes blocos de terra que caem no canal do rio, responsáveis pelo assoreamento e pela perda de terras produtivas. Foi identificada a falta de uma atitude de preservação por parte dos ribeirinhos, constituindo-se em constante ameaça para a biodiversidade dos ecossistemas ripários.

Palavras-chave: Levantamento florístico, vegetação ciliar, desestabilização de taludes e rio São Francisco.

\section{INTRODUCTION}

The São Francisco River Basin has been subjected to development policies, mainly the installation of hydroelectric dams through the river channel and surface water withdrawal for irrigation of public and private lands. As a result of the construction of these dams, land adjacent to floodplain was flooded and the river flow regime was altered. In the lower São Francisco River, which borders the states of Sergipe and Alagoas, in northeastern Brazil (Fig. 1), serious disturbances in the major extension of the riparian ecosystem along the river margin has led to riverbank destabilization, increasing its erosion, stream lateral migration and sedimentation, which is reflected directly in the numbers of sand bars. In effect, erosion is commonly caused by the exposure of soil, due to the loss of vegetation which covers and protects the riverbank, as reported by Kageyama et al. (1994). Although soil parameters and riverbank characteristics are not enough information for a precise diagnostic of bank instability (HUNT, 1990), a reasonable prediction of the bank ruptures can be provided by the qualitative evaluations of various elements influencing the riverbank instability.

Because of the river basin's vulnerability to erosion and the unsustainable activities conducted there, the flora has been the natural resource most rapidly and easily threatened. Riparian vegetation on the riverbank has been seriously and continuously deforested because of roads, hydroelectric power dams construction, urban occupation, adjacent land use, irrigated agriculture, livestock grazing, and the extraction of wood and minerals. Recent studies in the Lower São Francisco River showed that only $4 \%$ of the total edges still have riparian vegetation, while the other $96 \%$ of the river margin have been threatened and continuously replaced by pasture/agriculture systems (ZUCON et al., 1996).

Most of these riparian vegetation remnants are an extension of the Atlantic rain forest, that used to cover 100 million hectares in the Brazilian Atlantic Coast, now reduced to isolated patches (FUNDAÇÃO ..., 1999; PITHER and KELLMAN, 2002). According to Myers et al. (2000), this is an area featuring exceptional concentrations of endemic species and experiencing exceptional loss of habitat.

In the state of Sergipe, the Atlantic rain forest, which includes part of the riparian remnants, is characterized, mostly by secondary forest (ZUCON et al., 1996). Currently these fragments are still exposed to predatory exploitation, caused by fire, wood extraction and cattle grazing, even though they are considered "protected by law". The objective of this work was to study riparian vegetation remnants threatened by the current process of bank erosion in the Lower São Francisco River Basin.

\section{MATERIALAND METHODS}

\subsection{Study area}

This study was carried out on the margins of the Lower São Francisco River Basin, located in Sergipe State, Northeastern Brazil, from the Municipality of Propriá $\left(10^{\circ} 12^{\prime} \mathrm{S}, 36^{\circ} 50^{\prime} \mathrm{W}\right)$ through the Municipalities of Santana do São Francisco (10¹8'S, 36 $52^{\circ}$ 'W), Neópolis (10¹9'S, 36³4'W), Ilha das Flores (10²6'S, 36³2'W) to the river estuary, located in the Municipality of Brejo Grande (10²5'S, 36 $\left.07^{\circ} \mathrm{W}\right)$ (SERGIPE, 1997) (Fig. 1).

In the State of Sergipe, the lower sub-basin has a length of $236 \mathrm{~km}$ between its northwestern border and the mouth of the river, covering $37 \%$ of the overall state area, and $1.2 \%$ of the overall São Francisco River Basin. The extension between the Municipality of Propriá and the river estuary is $80 \mathrm{~km}$ long, covering $34.4 \%$ of the lower river basin (SERGIPE, 1997). The estuarine wetlands located at the mouth of the river in the Southwestern Atlantic (Border of Sergipe and Alagoas States) form a particularly important, environmentally sensitive interface between riverine and marine ecosystems (FONTES, 2002).

In the studied area a wide variety of soil types has been identified, such as patches of ustifluvent, haplustox, and haplustult (HOLANDA 2000), favoring the development of different ecosystems and providing

\section{R. Árvore, Viçosa-MG, v.29, n.2, p.327-336, 2005}


important information on the identification of the vegetation in each municipality, correlated to the remnants riparian patches. The annual average temperature is $26^{\circ} \mathrm{C}$ and rainfall varies from $806 \mathrm{~mm}$ to $1200 \mathrm{~mm}$ per year, with a pronounced dry season from September to February (SEPLAN, 1979).

\subsection{Vegetation survey}

Six fragments of riparian vegetation were chosen to be studied, based on local information on the less disturbed sites, located at Ilha do Aurélio, Morro do Aracaré, Fazenda Cajuípe, Ilha do Cachimbão, Ilha do Monte, and Povoado Cabeço. These sites are located in the municipalities of Propriá, Santana do São Francisco, Neópolis, Ilha das Flores, and Brejo Grande, respectively.

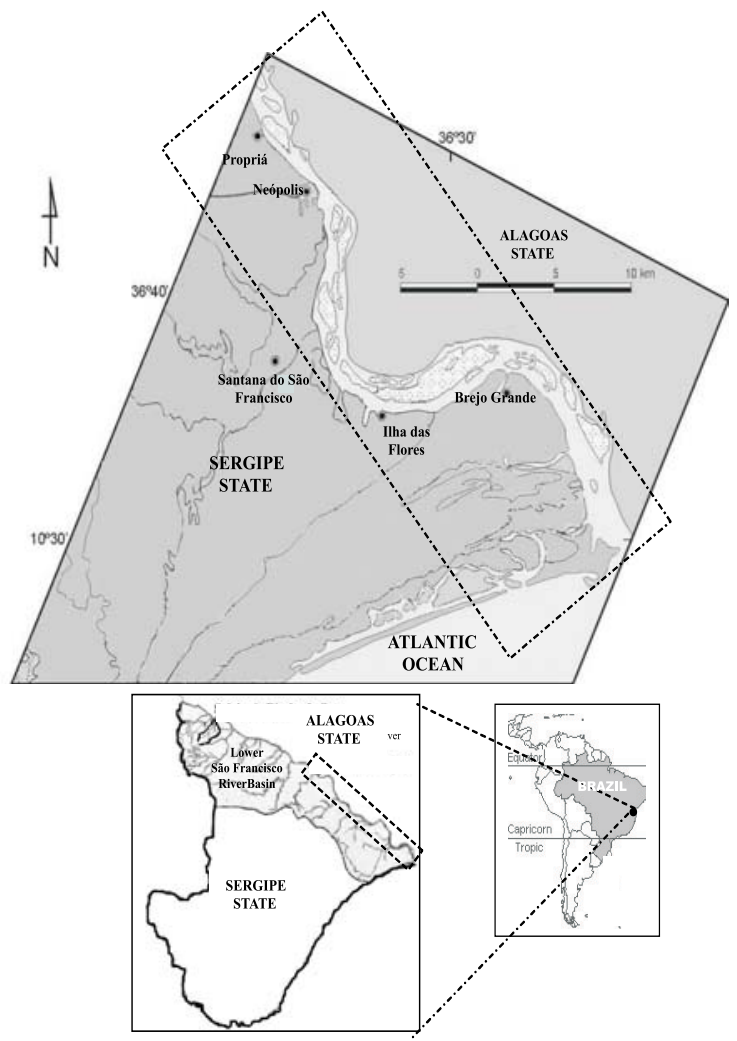

Figure 1 - Location of the study area, along the Lower São Francisco River.

Figura 1 - Localização da área de estudo, no baixo rio São Francisco.
At these places a floristic survey of trees, shrubs, herbs, grass, aquatic species, and others was performed, characterizing fragments of deciduous and semideciduous forest (alluvial semi-deciduous forest). The forest was sampled in 10 x 50 meters. Each species was collected, mounted, labeled, and systematically arranged in a herbarium, as described in Mori et al. (1989). Plant species data were listed according to the classification system of Cronquist (1981).

\subsection{Historic riparian deforestation survey}

In order to obtain relevant information regarding the past deforestation, a semi-structured questionnaire was applied according to Trivinos (1995). A group of 260 people was interviewed among fishers, farmers, landowners, and others, who live in the studied riverine area. Additionally, information on the five less disturbed sites in the river margin was collected through the interview with key informers (PELTO and PELTO, 1978). The interviewers' questions were designed to determine the knowledge of the local population about river margin changes, related to riparian vegetation deforested species, and its influence on the river bank erosion over the years. This population was selected for the survey because they live and work in that area, and exert a strong pressure on the natural resources in those ecosystems. This survey employed a non-random and non-probalistic assessment data analysis, considering that the participants responded to questionnaires applied by the interviewers, who have a previous knowledge about the sampled population intrinsic characteristics (LEVIN, 1978).

\subsection{River banks stability}

In order to understand the stability of riverbanks, three different sites (A, B and C), located in the Municipality of Propriá (Cotinguiba-Pindoba Irrigated Perimeter), were selected. These sites were selected in 1999 (CASADO et al., 2002), based on the presence and characteristics of their vegetation cover, bank height, soil particles composition and riverbank erosion stage process, representing the most common soil type such as alluvium soils. The chosen sites A, B and C were mostly covered by grass-shrubs, vegetable crop field and by grass and scarce trees, respectively, and are different from the sites where the floristic survey was perfomed. These essays were arranged in a randomized block design, with three replications. The estudied

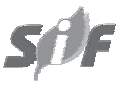

R. Árvore, Viçosa-MG, v.29, n.2, p.327-336, 2005 
sites were basically composed by sand layers characterized as alluvial soils.

The characteristics of material property strengths from the soil horizons were achieved by Mohr-Coulomb material strength criteria for assessing stability, through the calculation of the Factor of Safety (FS). The FS is therefore chosen as a ratio of the available shear strength required to keep the riverbank stable (BURNS, 1999). The data closeness to 1 , means stability to the river slope. The software XSTABL was used to process data provided by the Bishop/Jambu Method in order to determine how stable the riverbank is and which conditions are needed to reactivate these landslides (SHARMA, 1994), allowing for the calculation of the FS of a known failure plane.

\section{3 - RESULTS AND DISCUSSION}

\subsection{Composition of the riparian vegetation remnants and deforestation}

The São Francisco River has a progressive transition of ecosystems from downstream to upstream, with mangrove along the sand coastal plain "restinga," Atlantic rain forest, Brazilian savanna "cerrado," and semi-arid ecosystem "caatinga." In all sampled sites, replacement of native species by invading species from the ecosystems near the riparian zone were noticed, as previously reported by Rodrigues e Leitão Filho (2000). This riparian landscape is a mosaic of distinct ecological formations that works as a corridor, linking different phyto-ecological regions.

Between the river estuary and the Municipality of Propriá, 51 botanic families distributed in 71 genera and 79 plant species were identified, predominantly from the families Mimosaceae, Myrtaceae, and Fabaceae.

At Povoado Cabeço located in the river estuary, Municipality of Brejo Grande, very fragmented riparian vegetation was found, a consequence of logging by landholders, leading to an increase in beach and rivermarine erosion. A great number of mangrove trees was reported, and also an endemic specie of the São Francisco river estuary such as Craenea sp., called by the local population "manchica", (PETROBRAS, 2000). This species plays a colonizer role in the natural vegetation succession, commonly established in mangrove's edge and in the sand bars. Other species were reported firstly by Franco (1983), belonging to the sand coastal plain. In this ecosystem 19 botanic families were found, distributed in 24 plant species (Table 1).

R. Árvore, Viçosa-MG, v.29, n.2, p.327-336, 2005
The riverbank in the Ilha do Monte, Municipality of Ilha das Flores, is mostly covered by aquatic species, mainly because the original forest was replaced by coconut. A mosaic of shrubs and small trees from 7 different families were identified such as Araceae, Gramineae, Hydrocaritaceae, Onagraceae, Pontederiaceae, Sapindaceae, and Scrophulariaceae, each one represented by one species (Table 1).

The three following sites: Ilha do Cachimbão, Morro do Aracaré, and Fazenda Cajuípe have also presented a great reduction in the number of primary species, which have been replaced by isolated fragments of secondary vegetation, considered as invading species.

At Ilha do Cachimbão, a less disturbed riparian vegetation was found, mostly characterized by a shrubtree stratum. In the central part of this small "island," a continuous threat toward the forest devastation has been correlated to grazing activities, leading to the observation of only small patches of the riparian forest. Thus, this fragment was classified into 16 families distributed in 19 plant species, mainly from the family Mimosaceae, and native species also identified from the Atlantic rain forest ecosystem.

Morro do Aracaré still presents an area predominantly populated by shrubs and scattered trees, where the overall deforestation was avoided perhaps due to difficulties in accessibility by the riverine population, such as the high slope of the hill accessed only by boat. According to the floristic survey, in this site 20 different botanic families were found distributed in 27 plant species predominantly from the family Mimosaceae (Table 1). Those species were previously reported by Leitão Filho (1982), as very common in the Atlantic rain forest.

At Fazenda Cajuípe, the riparian vegetation deforestation initially occurred because of the expansion of sugar cane fields (PORTO, 1999), a very common disturbance and most of the time associated to the Atlantic forest degradation in Brazil (GASCON et al., 2000), related to woodcutting to provide fuel for small local sugar cane mills. Throughout the years, Cocos nucifera (coconut) has occupied part of this area, because of the suitable agro ecological conditions. Regardless of the strong coconut's presence, the remnant riparian vegetation showed 15 families distributed in 20 different genera and 22 species. These species were previously reported (FRANCO, 1983) as being part of different ecosystems such as coastal plain, Atlantic forest, and "caatinga". 
Riparian vegetation affected by bank erosion in the...

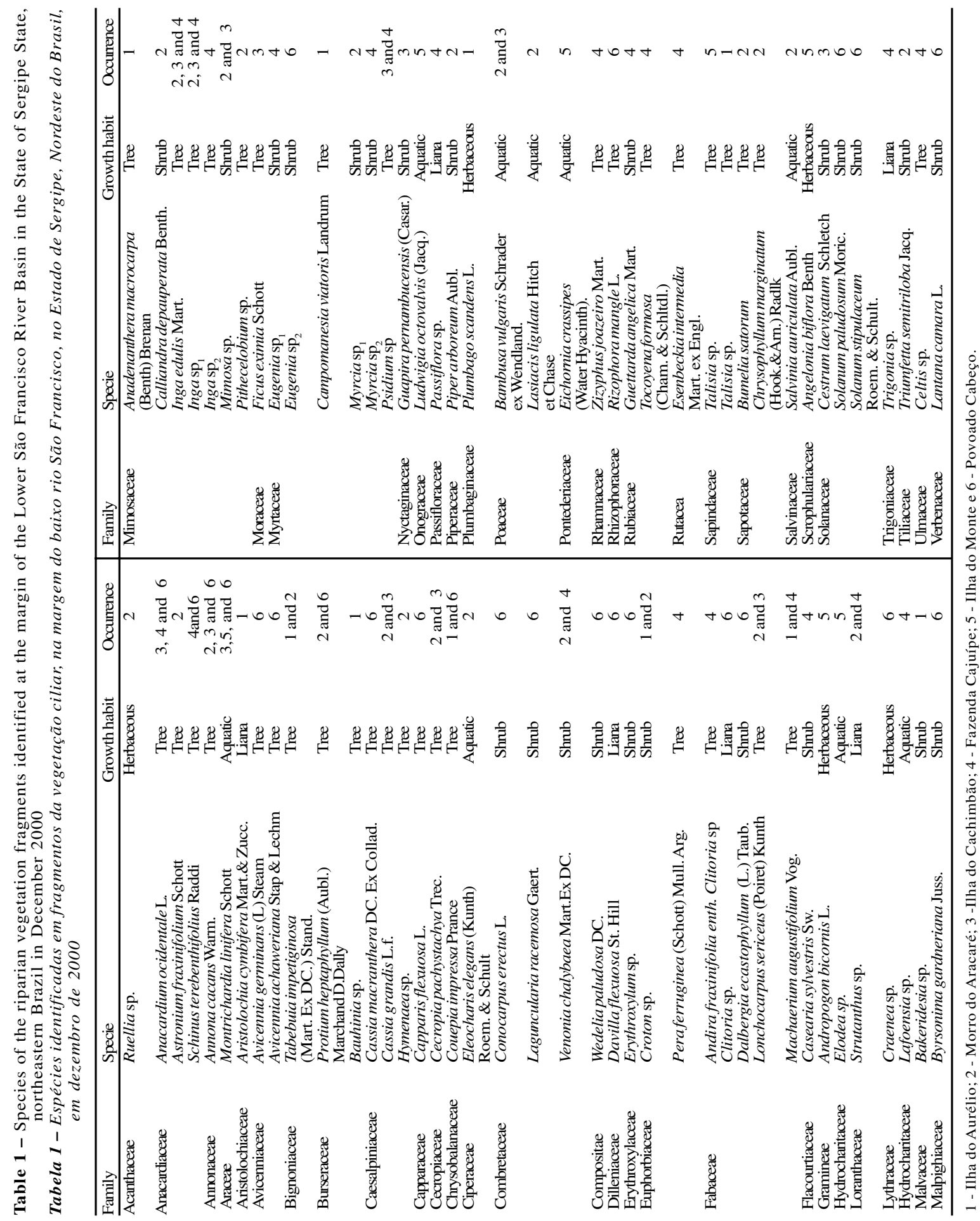

R. Árvore, Viçosa-MG, v.29, n.2, p.327-336, 2005 
At the Ilha do Aurélio the riparian vegetation was greatly reduced mostly because of anthropogenic activities, leading to a remarkable bank erosion processes. Thus, only few riparian fragments were identified, presenting 10 botanic families distributed in 11 plant species, some of them invading species from the river's basin semi-arid area.

From the river estuary to upstream toward the Municipality of Propriá, the most broadly distributed species along the riverbanks were Inga edulis, Montrichardia linifera and Mimosa sp. Inga edulis Mart ("ingazeira") is a semi-deciduous tree, heliophyte, selective hygrophyla, commonly found in wetlands, which are mostly occupied by secondary species. It is also very abundant along margins of large rivers, developing very fast as pioneer species in secondary ecological succession. M. linifera (Arruda) Shott ("aninga") was also found spread from the Municipality of Santana do São Francisco until the river estuary. It is a pioneer species near the mangrove ecosystem and in the sand bars, characterized as aquatic herbaceous plant, measuring up to five meters tall and $20 \mathrm{~cm}$ or more in diameter, with straight and fusiform trunk. Mimosa sp. ("calumbi") is a nitrogen-fixing shrub, that colonizes land after clearing or burning. It grows quickly, providing cover and extra nitrogen to the soil for slower growing plants. It can be found broadly distributed from the Municipality of Propriá to the Municipality of Ilha das Flores.

Other plant species are also very common along the river margin, such as Bambusa vulgaris ("caniço"), Eleocharis elegans ("junco") and Eichornia crassipes ("balseiro"), mostly covering wetlands, protecting the riverbank against the force of the water waves. In agreement with Nilsson et al. (1989), it was noticed that species like Eleocharis sp. presented dense root network growth that binds bank sediments and resists plant removal by flood scour.

\subsection{Changes in the riparian vegetation throughout the years}

According to opinions of the riverine population, the riparian vegetation has been submitted to a very serious anthropogenic degradation throughout the years, with a strong shift to a higher density of aquatic species mainly from the families Hydrocharitaceae and Scrophulariaceae, such as Elodea sp. ("cabelo") and
Bacopa myriophylloides ("lodo"), thus now very common in the river channel. Several people tried to link the remarkable presence of those aquatic species to the lack of natural river flooding season, because the past strong flow used to remove plants from the main river channel. Also, the absence of sediments in the clear water released by the electricpower dams, allows more sunlight to penetrate into the deep river water. This situation together with the river sedimentation because of the riverbank erosion, has created favorable conditions for those fast propagated species. In addition people also report that body contact with Elodea sp. irritates the skin of fishers, probably related to the calcium oxalate produced by this plant, and stongly contributing to hide fish.

Beyond the above-cited species, strongly spread in all Lower São Francisco River, a grass called Andropogon bicornis ("rabo-de-raposa"), also very common, causes serious navigation problems and complaints from the local fishers.

A list of plant species previously found in the river margin according to the local people, included Inga edulis, Eichornia crassipes, Mimosa sp., Bambusa vulgaris, Eleocharis elegans and Montrichardia linifera, as very common in the past years, and still widespread in the region (Table 2). The presence of Cocos nucifera, is also very frequent, even though it is mostly found in the Municipality of Neópolis where its commercial production is still very common, and in the Municipality of Brejo Grande, in the sand coastal plain ecosystem, ecologically favorable to coconut propagation. In both sites, the plants are widely spaced according to the current harvest techniques, adding river margin disturbances. Other species are present in small fragments patches, explaining the strong loss of genetic biodiversity.

In the riparian vegetation, the density of some species that were not very common in the past, has increased. Besides Elodea sp. other species such as Cassia grandis ("canafístula"), Piper arboreum ("pipeira"), Laguncularia racemes ("mangue branco"), and Mangifera indica ("manga"), were frequently cited. In the mangrove ecosystem an increase in the density of Inga edulis was noticed. The frequency of certain species such as Mangifera indica can be explained by the increase in commercial production mango fields, located in irrigated areas near the river margin, also contributing to the riparian vegetation degradation. 
Table 2 - Species of the original riparian cover in the lower São Francisco riverbanks in the State of Sergipe State, northeastern Brazil, according to the questionaire applied to the local population, in December 2000

Tabela 2 - Espécies da vegetação ciliar original nas margens do baixo Rio São Francisco, Estado de Sergipe, Nordeste do Brasil, de acordo com o questionário aplicado à população local, em dezembro 2000

\begin{tabular}{|c|c|c|c|c|}
\hline Family & Specie & Common Name & Growth Habit & Occurrence \\
\hline Anacardiaceae & Anacardium ocidentale $\mathrm{L}$. & Caju & Tree & 1,3 and 5 \\
\hline Anacardiaceae & Mangifera indica $\mathrm{L}$. & Mangueira & Tree & $1,2,3$ and 4 \\
\hline Anacardiaceae & Spondias dulcis Forst. & Cajazeira & Tree & 3 and 5 \\
\hline Annonaceae & Annona cacans Warm. & Araticum & Tree & 5 \\
\hline Araceae & Montrichardia linifera Schott & Aninga & Aquatic & 4 \\
\hline Arecaceae & Cocos nucifera $\mathrm{L}$ & Coco, Coconut & Tree & $2,3,4$ and 5 \\
\hline Bignoniaceae & Tabebuia caraiba Mart. & Craibeira & Tree & 1 \\
\hline Caesalpiniaceae & Cassia fistula $\mathrm{L}$ & Canafístula & Tree & 1,2 and 4 \\
\hline Caesalpiniaceae & Caesalpinea pyramidalis Tull. & Catingueira & Tree & 1 \\
\hline Cecropiaceae & Cecropia pachystachya Trec. & Umbaúba & Tree & 4 \\
\hline Chrysobalanaceae & Couepia impressa Prance & Maçãnzeira & Tree & 1 \\
\hline Ciperaceae & $\begin{array}{l}\text { Eleocharis elegans (Kunth) } \\
\text { Roem. \&Schult }\end{array}$ & Junco & Aquatic & 2 and 3 \\
\hline Combretaceae & Terminalia catalpa $\mathrm{L}$ & Amendoeira & Tree & 1 \\
\hline Convolvulaceae & Ipomoaea fistulosa Mart. & Mata-cobra & Herb & 1 \\
\hline Fabaceae & Dalbergia ecastophyllum (L.) & Bugio & Shrub & 5 \\
\hline Flacourtiaceae & Casearia sylvestris $\mathrm{Sw}$. & Maria-preta & Shrub & 5 \\
\hline Meliaceae & Cedrela fissilis Vell. & Cedro & Tree & 1 \\
\hline Mimosaceae & Inga edulis Mart. & Ingazeira & Tree & $1,2,3,4$ and 5 \\
\hline Mimosaceae & Mimosa sp. & Calumbi & Shrub & 1,3 and 4 \\
\hline Moraceae & Ficus eximia Schott & Gameleira & Tree & 1 \\
\hline Myrtaceae & Eugenia sp. & Cambuí & Tree & 5 \\
\hline Myrtaceae & Psidium sp. & Araçá & Shrub & 4 and 5 \\
\hline Passifloraceae & Passiflora sp. & Maracujazeiro & Liana & 5 \\
\hline Piperaceae & Piper arborium Aubl. & Pipeira & Strub & 1,3 and 4 \\
\hline Poaceae & $\begin{array}{l}\text { Bambusa vulgaris Schrader } \\
\text { ex Wendland. }\end{array}$ & Caniço & Aquatic & 1 and3 \\
\hline Poaceae & Oryza sativa $\mathrm{L}$. & Arroz & Herb & 1 and 3 \\
\hline Pontederiaceae & Eichornia crassipes (Martius) & Balseiro & Aquatic & $1,2,3,4$ and 5 \\
\hline Rhamnaceae & Zizyphus joazeiro Mart. & Joazeiro & Tree & 1 \\
\hline Rosaceae & Licania humilis Cham. \& Schlecht & Oiti & Tree & 5 \\
\hline Rubiaceae & Anisomeris sp. & Espinho branco & Shrub & 5 \\
\hline Rubiaceae & Genipa americana $\mathrm{L}$. & Jenipapeiro & Tree & 1,2 and 3 \\
\hline Rubiaceae & Guettarda angelica Mart. & Rompe-gibão & Strub & 1 and 2 \\
\hline
\end{tabular}

1 - Municipality of Propriá; 2 - Municipality of Santana do São Francisco; 3 - Municipality of Neópolis; 4 - Municipality of Ilha das Flores; 5 - Municipality of Brejo Grande.

Based on the local population opinions it seems that Inga edulis, the most frequently mentioned species, has developed an important role as a river's margin protector, followed by Eichornia crassipes and Montrichardia linifera. It was noticed that those answers are in accordance with the empirical published data by Franco (1983). Mimosa sp. has been also used as a bank protector species by the riverine population, although this species seems more common in the upper part of the river. On the other hand, Inga edulis and Montrichardia linifera were found densely populating the studied area, offering a good protection to the river margin.

\subsection{River Bank Stability}

Casado et al. (2002), reported an ascending accumulated erosion rate of $8.30 \mathrm{~m}$ per year from 1999 to 2001 in site A, while sites B and C had an accumulated

R. Árvore, Viçosa-MG, v.29, n.2, p.327-336, 2005 
rate of 47.3 and $4.45 \mathrm{~m}$ per year, respectively (Table 3 ). The three sites studied had different results of Factor of Safety (FS) related to bank instability, and all were classified as unstable. Only the site $\mathrm{C}$ has presented FS of 0.975 , close to a situation of equilibrium. The FS used to explain the riverbank stability results, is the ratio of the available shear strength to the minimum shear strength needed for equilibrium, explained as an interactive method. According to this definition a bank (slope) is unstable when the Factor of Safety is lower than 1. The FS of 0.975 calculated for site C, may be explained by its low bank height. In this site the soil is mostly dominated by silt and clay fractions and the present vegetation in the bank was predominately grass and sparse trees. According to Tschebotarioff (1978), erosion occurs particularly faster in the bank dominated by silt and very fine sand, which have very low cohesion.

Because of the very low cohesion forces of the soil particles in the bank, there is an urgent need of riverbank stabilization along the river margin. Strong species that withstand the waves present in the river are needed to reduce the constant landslides that are mainly responsible for the river sedimentation and loss of productive lands. A similar conclusion was reached for bank stability because the soils are predominantly alluvial such as haplustult and ustifluvent. These soils are characterized by variations in resistance to soil rupture, both vertically and horizontally (SANTOS, 2002). Thus, vegetative protection could help control the erosion process, even in very vertical and high

Table 3 - Classification of slope stability in the studied sites (A, B and C) based en the factor of safety (FS), in the lower São Francisco riverbanks in the State of Sergipe State, northeastern Brazil, in December 2000

Tabela 3 - Classificação da estabilidade do talude nos sítios estudados ( $A, B$ e $C)$, baseado no fator de segurança (FS), no baixo rio São Francisco, Estado de Sergipe, Nordeste do Brasil, em dezembro 2000

\begin{tabular}{lcccc}
\hline Site & $\begin{array}{c}\text { Bank mean } \\
\text { Height }(\mathrm{m}) *\end{array}$ & $\begin{array}{c}\text { Erosion Rate } \\
(\mathrm{m} \text { per year) }\end{array}$ & FS** & $\begin{array}{c}\text { Slope } \\
\text { Stability*** }\end{array}$ \\
\hline A & 5.21 & 8.30 & 0.463 & Unstable \\
B & 6.36 & 47.30 & 0.663 & Unstable \\
C & 3.91 & 4.45 & 0.975 & Unstable \\
\hline Adapted from Casado et al. (2002). \\
*Measured from the base (river water level) to the botton (soil surface). \\
** FS $\geq 1$, means bank slope stable. \\
*** Susceptibility do landslide.
\end{tabular}

R. Árvore, Viçosa-MG, v.29, n.2, p.327-336, 2005 riverbanks. Few shrubs and vegetable crop fields, which are the predominant vegetation cover present in the studied sites A and B, respectively, did not provide enough protection to avoid erosion, thus the bank is highly unstable and susceptible to erosion. This was mainly related to sandy composition, low vegetation cover and closeness to talweg.

The fast and progressive bank erosion process mostly occurs when waves hit the unprotected riverbanks; expose the root systems and eventually causing trees to fall into the stream. Montrichardia linifera can minimize this serious environmental problem in the lower São Francisco River basin, and should be listed in re-vegetation plans for this area, since it is easily adapted to wetlands, propagates rapidly and is recognized as a colonizer species. Additionally, wet meadow riparian vegetation, here represented by Eleocharis elegans, is another good example. Its roots appear to increase bank strength by reinforcing soils (MICHELI and KIRCHNER, 2002).

There is a strong and urgent need to restorate the riparian zone with native or exotic plant species that have a fast vegetative development, in order to reduce riverbank erosion. Nevertheless, the preservation of riparian remnants is vital because they produce source of plant seeds, provide home for pollinators and dispersal agents, and contribute enormously to the recovery of the riparian zone.

Species that yield fruits, flowers for honey production and medicines could be planted in the Lower São Francisco to stimulate the landholder's involvement in the restoration process, and recover its biodiversity.

\section{4-ACKNOWLEDGMENTS}

We are Thankful to Professor Gilvane Viana for field and laboratory assistance, to Mrs. Esther Alsum, Mr. Francisco Arriaga and Prof. Joy Zedler for their comments on an earlier draft.

\section{5- LITERATURE REFERENCES}

BURNS, W. J. Engineering geology and relative stability of the Southern half of Newell Creek Canyon, Oregon City, Oregon. Master thesis, Portland State University. <http:// nwdata.geol.pdx.edu/Thesis/fulltest/1999/ BurnsW> 1999. Date of access: Oct. 2002. 
CASADO, A.P.B. et al. Evolução do processo erosivo na margem direita do rio São Francisco. Brazilian Journal of Soil Science, v.26, n 1, p.231-239, 2002.

CRONQUIST, A. An integrated system of classification of flowering plants. New York, Columbia University Press: 1981. 1262p.

FONTES, L.C. Erosão marginal associada a impactos ambientais a jusante de grandes barragens: $O$ caso do baixo curso do Rio São Francisco. 2002. 321f. Tese (Mestrado em Desenvolvimento e Meio Ambiente) -

Universidade Federal de Sergipe, 2002.

FRANCO, E. Biogeografia do Estado de Sergipe. Aracaju: UFS. 1983. 128p.

FUNDAÇÃO S.O.S. Mata Atlântica. Recursos florestais da mata atlântica: a exploração e utilização dos recursos, seus impactos sócio-econômicos atuais e potencialidades de manejo sustentável. São Paulo: EMBRAPA/CNRBMA/ SMA; 1999. 150p.

GASCON, C.; WILLIANSON, G.B.; FONSECA, G.A.B. Receding forest edges and vanishing reserves. Science, v.288, p.1356-1358, 2000.

HOLANDA, F.S.R. Estudo integrado do vale do São Francisco sergipano: região de tabuleiros costeiros e pediplano sertanejo-pedologia. Aracaju: CODEVASF, 2000, (CD-ROM)

HUNT, E. Judgment Assessment of Slopes in Tropical Climates (Solos e Rochas). Revista Brasileira de Geotecnia, v.13, p.46-64, 1990.

KAGEYAMA, P.Y. et al. Revegetação de áreas degradadas: modelos de consorciação com alta diversidade. In: SIMPÓSIO SUL-AMERICANO, 1; SIMPÓSIO NACIONAL SOBRE RECUPERAÇÃO DE ÁREAS DEGRADADAS, 2., 1994, Foz do Iguaçu, 1994. Anais... Curitiba: FUPEF, 1994. p.569-576.

LEITÃO FILHO, H. F. Aspectos taxonômicos das florestas do Estado de São Paulo. Silvicultura em São Paulo, v. 16, n. 1, p. 197-206, 1982.
LEVIN, J. Estatística aplicada a ciências humanas. 2. ed. São Paulo: Harbra, 1978. 392p.

MICHELI, E.R.; KIRCHNER, J.W. Effects of wet meadow riparian vegetation on stream bank erosion. 1. Remote sensing measurement of stream bank migration and erodibility. Earth Surface Process and Landform., v.27, n.2 , p.627639, 2002.

MORI, S.A. et al. Manual de manejo do herbário fanerogâmico. Ilhéus: CEPLAC, 1989. 104p.

MYERS, N. et al. Biodiversity hotspots for conservation priorities. Nature, v.403, p.853-858, 2000.

NILSSON, C. et al. Patterns of plant species richness along riverbanks. Ecology, v.70, p.7784, 1989.

PELTO, P.S.; PELTO, G.H. Anthropological research the structure of inquiry. 2. ed. Cambridge: Cambridge University Press, 1978. 353p.

PETROBRÁS. Vegetação e flora do litoral sergipano: relatório de avaliação ambiental. PETROBRAS/FAPESE, Aracaju: 2000. 55p.

PITHER, R.; KELLMAN, M. Tree species diversity in small, tropical riparian forest fragments in Belize, Central America. Biodiversity and Conservation, v.11, p.1623-1636, 2002.

PORTO, P.R.M. Situação florestal do Estado de Sergipe e subsídios para um plano de recomposição. Sergipe, Brazil. 1999. 110f. Tese (Mestrado em Desenvolvimento e Meio Ambiente) - Universidade Federal de Sergipe, Sergipe, 1999.

RODRIGUES, R. R.; LEITÃO Filho, H. F. (Eds.) Matas ciliares : conservação e recuperação. São Paulo : EDUSP/FAPESP, 2000. 320p.

SAntos, C.M. A erosão no baixo São Francisco Sergipano e os mecanismos de desestabilização dos taludes na margem do rio. Sergipe, Brasil. 2002.130f. Tese (Mestrado em Desenvolvimento e Meio Ambiente) - Universidade Federal de Sergipe, Sergipe, 2002.

R. Árvore, Viçosa-MG, v.29, n.2, p.327-336, 2005 
SEPLAN. Atlas de Sergipe. Aracaju: UFS, 1979. 180p.

SERGIPE. Secretaria de Estado do Planejamento e da Ciência e Tecnologia. Brejo Grande. In: Perfis municipais. Aracaju: SEPLANTEC. 1997. 202p.

SHARMA, S.. XSTABL, An integrated slope stability analysis program for personal computers, Version 5. Moscow: Interactive Software Designs, 1994.
TRIVINOS, A.N.S. Introdução e pesquisa em ciências sociais: a pesquisa quantitativa em educação. São Paulo: Atlas, 1995. 175p.

TSCHEBOTARIOFF, G.P. Fundações, estruturas de arrimo e obras de terra. São Paulo: Mcgraw-Hill, 1978. 520p.

ZUCON, M.H. et al. Educação ambiental em torno dos remanescentes de mata atlântica de Sergipe. In: INTERNATIONAL SYMPOSIUM ON FOREST ECOSYSTEMS, 4., 1996, Belo Horizonte. Anais....Belo Horizonte: 1996. 334p. 